\title{
Genome Mining for Antimicrobial Compounds in Wild Marine Animals-Associated Enterococci
}

\author{
Janira Prichula ${ }^{1}$ (), Muriel Primon-Barros ${ }^{1}$ (), Romeu C. Z. Luz ${ }^{1}$, Ícaro M. S. Castro ${ }^{1}$, Thiago G. S. Paim ${ }^{1}$, \\ Maurício Tavares ${ }^{2}$, Rodrigo Ligabue-Braun ${ }^{3}{ }^{(0}$, Pedro A. d'Azevedo ${ }^{1}$, Jeverson Frazzon ${ }^{4}$, Ana P. G. Frazzon ${ }^{5}{ }^{\circ}$, \\ Adriana Seixas ${ }^{3}$ and Michael S. Gilmore ${ }^{6,7, *}$
}

1 Gram-Positive Cocci Laboratory, Federal University of Health Sciences of Porto Alegre (UFCSPA), Porto Alegre 90050-170, RS, Brazil; janirap@ufcspa.edu.br (J.P.); murielp@ufcspa.edu.br (M.P.-B.); romeulu@ufcspa.edu.br (R.C.Z.L.); icaromsc@ufcspa.edu.br (Î.M.S.C.); thiagopucrs@gmail.com (T.G.S.P.); pedroaze@ufcspa.edu.br (P.A.d.)

2 Centro de Estudos Costeiros, Limnológicos e Marinhos (CECLIMAR), Universidade Federal do Rio Grande do Sul (UFRGS), Campus Litoral Norte, Imbé 95625-000, RS, Brazil; mauricio.tavares@ufrgs.br

3 Department of Pharmacosciences, UFCSPA, Porto Alegre 90050-170, RS, Brazil; rodrigolb@ufcspa.edu.br (R.L.-B.); adrianaseixas@ufcspa.edu.br (A.S.)

4 Food Science Institute, UFRGS, Porto Alegre 90035-003, RS, Brazil; jeverson.frazzon@ufrgs.br

5 Department of Microbiology, Immunology and Parasitology, UFRGS, Porto Alegre 90050-170, RS, Brazil; ana.frazzon@ufrgs.br

6 Massachusetts Eye and Ear Infirmary, Department of Ophthalmology, Harvard Medical School, Boston, MA 02114, USA

7 Department of Microbiology, Harvard Medical School, Boston, MA 02115, USA

check for updates

Citation: Prichula, J.; Primon-Barros, M.; Luz, R.C.Z.; Castro, Í.M.S.; Paim, T.G.S.; Tavares, M.; Ligabue-Braun, R.; d'Azevedo, P.A.; Frazzon, J.; Frazzon, A.P.G.; et al. Genome Mining for Antimicrobial Compounds in Wild Marine Animals-Associated Enterococci. Mar. Drugs 2021, 19, 328. https://doi.org/10.3390/md19060328

Academic Editor: Max Crüsemann

Received: 1 May 2021

Accepted: 3 June 2021

Published: 6 June 2021

Publisher's Note: MDPI stays neutral with regard to jurisdictional claims in published maps and institutional affiliations.

Copyright: () 2021 by the authors. Licensee MDPI, Basel, Switzerland. This article is an open access article distributed under the terms and conditions of the Creative Commons Attribution (CC BY) license (https:// creativecommons.org/licenses/by/ $4.0 /)$.

* Correspondence: michael_gilmore@meei.harvard.edu

\begin{abstract}
New ecosystems are being actively mined for new bioactive compounds. Because of the large amount of unexplored biodiversity, bacteria from marine environments are especially promising. Further, host-associated microbes are of special interest because of their low toxicity and compatibility with host health. Here, we identified and characterized biosynthetic gene clusters encoding antimicrobial compounds in host-associated enterococci recovered from fecal samples of wild marine animals remote from human-affected ecosystems. Putative biosynthetic gene clusters in the genomes of 22 Enterococcus strains of marine origin were predicted using antiSMASH5 and Bagel4 bioinformatic software. At least one gene cluster encoding a putative bioactive compound precursor was identified in each genome. Collectively, 73 putative antimicrobial compounds were identified, including 61 bacteriocins $(83.56 \%)$, 10 terpenes $(13.70 \%)$, and $2(2.74 \%)$ related to putative nonribosomal peptides (NRPs). Two of the species studied, Enterococcus avium and Enterococcus mundtti, are rare causes of human disease and were found to lack any known pathogenic determinants but yet possessed bacteriocin biosynthetic genes, suggesting possible additional utility as probiotics. Wild marine animal-associated enterococci from human-remote ecosystems provide a potentially rich source for new antimicrobial compounds of therapeutic and industrial value and potential probiotic application.
\end{abstract}

Keywords: enterococci; genome-wide analysis; bacteriocins; probiotics; wild marine species

\section{Introduction}

Drug-resistant bacteria kill an estimated 700,000 people worldwide each year, and the discovery of new antimicrobial drugs is urgently needed [1-3]. This is motivating the search for new ecologies for novel natural products of potential therapeutic value. Human-proximal terrestrial life has been screened for diverse natural products to a much greater extent than larger but less accessible marine ecosystems. Blue biotechnology (or marine biotechnology) is an emerging field that investigates the rich diversity of bioactive molecules produced by marine organisms with potential industrial and therapeutic 
applications [4-9]. Early successes include compounds derived from a gastropod (e.g., ziconotide, commercial name Prialt [10]), sponge (e.g., eribulin mesylate, commercial name Halaven [11]), cyanobacteria (e.g., dolastatin 10 [12], apratoxin A [13], and barbamide [14]), fungi (e.g., penicillipyrone A and B [15], and aszonapyrone A [16]), algae (e.g., neolaurene [17] and diphlorethohydroxycarmalol (DPHC) [18]), and bacteria (e.g., salinosporamide A [19], abyssomicin C [20], forazoline A [21], and farnesylquinone [22].

Recently, host-associated microbes also have drawn attention as a potential source for low toxicity agents compatible with host health but active against pathogenic microbes [23,24]. It was, therefore, of interest to us to explore marine animals from remote habitats for hostassociated microbes that encode novel natural product biosynthetic pathways. Further, we focused on host-associated enterococci, a genus of gut microbes associated with all classes of land animals studied [25], and with animals that have returned to the marine environment [26]. Although most enterococci exist as harmless commensals, some lineages of the species Enterococcus faecalis and Enterococcus faecium have emerged as leading causes of multidrug-resistant hospital infection [25,27-30].

Enterococci are known to produce bacteriocins with narrow to broad antimicrobial activity [31-33]. Bacteriocins have found use as natural antimicrobial agents so far, mainly in the food industry but could complement traditional antibiotics in controlling important human and animal pathogens [34,35]. Different classification schemes have been proposed for bacteriocins produced by Lactic Acid Bacteria (LAB), although still a subject of debate $[33,36,37]$. Class I bacteriocins are posttranslationally modified peptides with less than $10 \mathrm{kDa}$ that require enzymatic modification during biosynthesis, and thereby, the molecules have uncommon amino acids and structures that impact their properties [36]. Class II bacteriocins are also less than $10 \mathrm{kDa}$, although they are heat stable and unmodified peptides [36] with the exception of disulfide bridging, circularization, and methionine formylation [33]. This class has been subclassified: IIa-pediocin-like bacteriocins; IIbtwo-peptide bacteriocins; circular bacteriocins; leaderless; and other bacteriocins that do not fall into any of the recognized subclasses [33]. On the other hand, Class III bacteriocins are large-molecular-weight (more than $10 \mathrm{kDa}$ ) and heat-labile antimicrobial proteins usually composed of different domains [36]. Divergently, some authors have been classified circular bacteriocins as class IV [38] or as Class Ib [36] since these head-to-tail cyclized peptides whose $\mathrm{N}$ - and $\mathrm{C}$-termini are linked by a peptide bond, thereby rendering a circular molecule [36].

The bacteriocins synthetized by enterococci, enterocins, are generally small molecular weight (20-60 amino acids), often post-translationally modified peptides with cationic, hydrophobic, and heat-stable properties $[32,33,36]$. They vary in their mode of action, activity spectrum (restricted or broad), molecular mass, biochemical properties, and genetic origin $[33,39,40]$. Most known enterocins are produced by E. faecium and E. faecalis, but a few peptides have also been isolated from Enterococcus mundtii, Enterococcus avium, Enterococcus durans, Enterococcus hirae, and Enterococcus lactis $[33,38]$. Most characterized enterocins derive from enterococci associated with food, waste, feces, and gastrointestinal tract of humans and other animals $[32,33,41]$. Few have been described from enterococci from wild ecologies [8,26,42-44].

Traditionally, new bioactive compounds have been identified by screening microorganism extracts for biological activity or by amplification of new genes using polymerase chain reaction (PCR) [45-48]. These screening strategies are limited by time-consuming and laborious test methods [24,49]. Advances in molecular biology, bioinformatics, and genomics have been providing important new tools for exploration and development [50-52]. Genome screening has identified a large pool of potential compounds encoded by biosynthetic gene clusters (BGCs) in DNA databases [1,53-56]. The identification of new BGCs may be performed by applying algorithms based on indicators (e.g., evolutionary hallmarks, signature protein domains, and distant paralogs of primary metabolic enzymes) and using bioinformatic tools, such as antiSMASH5 [57] and BAGEL4 [58]. High throughput 
computational technologies are being used for screening, presumptive chemical elucidation, and understanding of activities and biological aspects of new compounds [7,24].

Therefore, genome mining may represent a fertile strategy for identifying new biomolecules for future therapeutic and industrial applications. In this sense, the aim of the present study was to examine 22 genomes of Enterococcus species isolated from fecal samples of 17 wild marine animals from remote ecologies for potential antimicrobial compounds and/or probiotics strains.

\section{Results}

\subsection{Diversity of Wild Marine Animals Associated-Enterococci}

The genomes of 22 Enterococcus spp. isolated from wild sea turtles, seabirds, and marine mammals were sequenced (Table 1). A summary of the sequencing statistics is presented in Supplementary Table S1. The genomes sizes were between $2.6-4.5 \mathrm{Mb}$, with GC contents ranging from $36.3 \%$ to $42.4 \%$. All genomes share average nucleotide identities (ANI) above 95\% with known species [59], confirming designation as Enterococcus avium (4.54\%); Enterococcus casseliflavus (13.64\%); Enterococcus faecalis (45.45\%); Enterococcus hirae (27.27\%); Enterococcus lactis (4.54\%); Enterococcus mundtii (4.54\%) species (Table 1; Supplementary Table S2).

\subsection{Marine Enterococcal Genomes Harbor Diverse Biosynthetic Gene Clusters (BGCs) Coding for Antimicrobial Compounds}

Two informatic packages, antiSMASH5 [57] and Bagel4 [58], accurately predict all known enterococcal bacteriocins whose properties have been well studied [32,33], including bacteriocin 31, bacteriocin T8, durancin $Q$, enterocin 96, enterocin1071A and 1071B, enterocin_A, enterocin B, enterocin CRL35, enterocin EJ97, enterocin SE-K4, enterocin P, enterocin $X \alpha$ and $X \beta$, enterolysin A, hiracin JM79, mundticin KS, and others. This also includes the E. faecalis cytolysin, a highly divergent two-component lantipeptide-type bacteriocin active against nearly all Gram positives [60], which also possesses lytic activity for some eukaryotic cells [61]. Therefore, antiSMASH5 [57] and Bagel4 [58] were used to mine the genomes of all 22 genomes for putative bacteriocin biosynthesis operons (Supplementary Table S3). This analysis identified one or more gene clusters encoding a bioactive compound precursor in each genome. In total, 73 antimicrobial compound BGCs were predicted, including $61(83.56 \%)$ bacteriocins, $10(13.70 \%)$ related to terpene synthesis, and $2(2.74 \%)$ related to putative nonribosomal peptides (NRPs). The NRPs biosynthetic gene clusters were found only in E. lactis genome (MP10-1), whereas terpene BGCs were found among E. casseliflavus (HT1-1, J2, J4), E. hirae (C7, DMW1-1, MP1-1, MP1-2, MP1-4, MP1-5), and E. mundtii (MP7-18) species (Supplementary Table S3). NRP and terpene BGCs were predicted only by antiSMASH5 [57], whereas bacteriocins were identified by both tools. 
Table 1. The description of the origin of enterococci genomes associated with wild marine animals.

\begin{tabular}{|c|c|c|c|c|c|c|c|c|c|}
\hline Animal & Common Name & Scientific Name & Age $^{1}$ & Code $^{2}$ & Collection Date & Location & Enterococci Genomes $^{3}$ & Species Identification (ANI ${ }^{5}$ ) & Collection from \\
\hline \multirow{3}{*}{ Sea turtles } & green turtle & Chelonia mydas & $\mathrm{Y}$ & 2 & 29-May-13 & Cidreira & GT3-2 & E. faecalis (98.38) & \multirow{14}{*}{$\begin{array}{l}\text { Prichula et al. } \\
\quad(2016) \\
\text { Prichula et al. } \\
(2020)\end{array}$} \\
\hline & green turtle & Chelonia mydas & $\mathrm{Y}$ & 1 & 25-Apr-14 & Tramandaií & GT6-1 & E. faecalis (98.53) & \\
\hline & hawksbill turtle & Eretmochelys imbricata & $\mathrm{Y}$ & 1 & 23-Dec-12 & Tramandaií & HT1-3 & E. casseliflavus (98.56) & \\
\hline \multirow{10}{*}{ Seabirds } & \multirow{3}{*}{ Magellanic penguin } & \multirow{3}{*}{ Spheniscus magellanicus } & \multirow{3}{*}{$\mathrm{Y}$} & \multirow{3}{*}{1} & \multirow{3}{*}{ 2-Nov-12 } & \multirow{3}{*}{ Cidreira } & MP1-2 & E. hirae $(98.37)$ & \\
\hline & & & & & & & MP1-4 & E. hirae (99.34) & \\
\hline & & & & & & & MP1-5 & E. hirae $(98.68)$ & \\
\hline & Magellanic penguin & Spheniscus magellanicus & $\mathrm{Y}$ & 2 & 27-Jul-13 & Cidreira & MP5-1 ${ }^{4}$ & E. faecalis (98.54) & \\
\hline & Magellanic penguin & Spheniscus magellanicus & $\mathrm{Y}$ & 1 & 19-Sep-13 & Imbeí & MP7-18 & E. mundtii (97.04) & \\
\hline & \multirow{2}{*}{ Magellanic penguin } & \multirow{2}{*}{ Spheniscus magellanicus } & \multirow{2}{*}{$\mathrm{Y}$} & \multirow{2}{*}{1} & \multirow{2}{*}{ 14-Oct-13 } & \multirow{2}{*}{ Cidreira } & MP8-1 ${ }^{4}$ & E. faecalis (98.52) & \\
\hline & & & & & & & MP8-17 ${ }^{4}$ & E. faecalis (98.67) & \\
\hline & Magellanic penguin & Spheniscus magellanicus & $\mathrm{Y}$ & 1 & 16-Oct-13 & Cidreira & $\mathrm{MP}-10^{4}$ & E. faecalis (98.52) & \\
\hline & Magellanic penguin & Spheniscus magellanicus & $\mathrm{Y}$ & 1 & 23-Dec-13 & Torres & MP10-1 & E. lactis (98.92) & \\
\hline & snowy-crowned tern & Sterna trudeaui & A & 2 & 4-Dec-13 & Arroio do Sal & ST1-20 & E. faecalis (98.63) & \\
\hline \multirow{6}{*}{$\begin{array}{l}\text { Marine } \\
\text { Mammals }\end{array}$} & dwarf minke whale & Balaenoptera acutorostrata & $\mathrm{Y}$ & 2 & 21-Jun-13 & Tramandaií & DMW1-1 & E. hirae (98.09) & \\
\hline & South American fur seal & Arctocephalus australis & - & 2 & 2-Aug-12 & Torres & B9 & E. faecalis (98.81) & \multirow{5}{*}{ Santestevan et al. (2015 } \\
\hline & South American fur seal & Arctocephalus australis & A & 2 & 2-Aug-12 & Xangri-laí & $\mathrm{C} 7$ & E. hirae (98.67) & \\
\hline & \multirow{2}{*}{ South American fur seal } & \multirow{2}{*}{ Arctocephalus australis } & \multirow{2}{*}{ A } & \multirow{2}{*}{2} & \multirow{2}{*}{ 12-Jul-12 } & \multirow{2}{*}{ Palmares do Sul } & $\mathrm{J} 2$ & E. casseliflavus (98.56) & \\
\hline & & & & & & & $\mathrm{J} 4$ & E. casseliflavus (98.57) & \\
\hline & South American fur seal & Arctocephalus australis & - & 2 & 21-Jul-12 & Tramandaií & L8 & E. avium (98.06) & \\
\hline
\end{tabular}

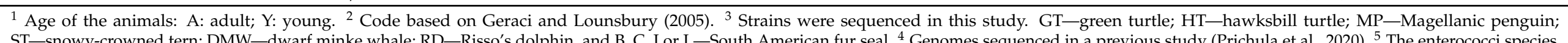

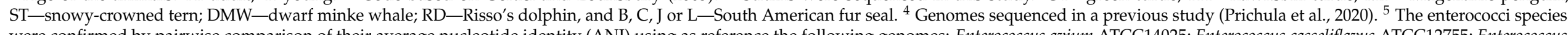

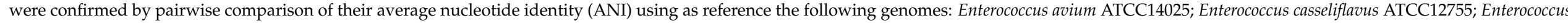
faecalis ATCC19433; Enterococcus hirae ATCC 9790; Enterococcus lactis KCTC 21015; Enterococcus mundtii ATCC 882. 


\subsection{Diversity of Bacteriocins Genes among Wild Marine Animals-Associated Enterococci}

A total of 30 unique bacteriocin species were identified, including 8 belonging to class I, 19 to class II, and 3 to class III (Figure 1). Although class II bacteriocins showed the greatest diversity, class III bacteriocins were most common and widely distributed. Interestingly, eight new putative bacteriocins with no significant identity to known peptides were found amongst marine enterococci genomes, including two new putative lanthipeptides (I and II) identified as class I, five unknown bacteriocins (I, II, III, IV, and V) identified as class II, and one unknown class III bacteriocin (VI) (Figure 1; Supplementary Table S4).

The most frequent class I bacteriocins were putative sactipeptides $(n=9)$, followed by unknown lanthipeptide $1(n=5)$, lasso peptides $(n=4)$, and thiopeptides $(n=4)$. Enterocin SE-K4 $(n=5)$ and enterocin P $(n=3)$ were the most frequent class II bacteriocins. In turn, the class III bacteriocin enterolysin A $(n=17)$ was the most frequent bacteriocin found in the 22 sequenced genomes (Figure 1 ).

Eight enterococcal genomes belonging to E. hirae (C7, DMW1-1, MP1-5), E. avium (L8), and E. faecalis (GT3-2, GT6-1, MP8-1, and ST1-20) species showed four or more bacteriocin biosynthetic genes (Figure 1). Four of these genomes (C7, DMW1-1, MP1-5, and MP8-1) encode bacteriocins belonging to three different classes (I, II, and III). Moreover, four enterococci genomes (C7, L8, ST1-20, and MP1-2) exhibited evidence of bacteriocin gene duplication (Figure 1; Supplementary Table S3). Because of their potentially new bacteriocins and/or amenability large-scale synthesis, putative class II and III bacteriocins were of special interest for further analysis.

\subsection{Phylogenetic Relationship among Class II and III Bacteriocins Predicted from Wild Marine Animal-Associated Enterococcal Genomes}

To gain insights into the phylogeny of the 30 class II and 19 class III bacteriocins genes identified, phylogenetic analysis was performed (Figure 2) to determine their relationship (Supplementary Table S5) to 16 reference sequences in Bagel4 and Uniprot databases (Supplementary Table S6). This identified two groups with significant branch support (Figure 2). Group 1 included bacteriocins of both classes II and III. Class II bacteriocin gene clusters in Group 1 could be divided into subclasses $\mathrm{a}, \mathrm{b}$, and others. Included within each are: IIa) mundticin AT06, enterocin P, bacteriocin T8, bacteriocin 31, and enterocin SE-K4; IIb) enterocin X chain alpha, enterocin X chain beta; II leaderless) enterocin EJ97; II circular bacteriocin) carnocyclin A; II other subclasses) sakacin $Q$, enterocin 96 , uviB, and enterocin NKR-5-3D; and unknown bacteriocins I, II, III, IV, and V. Class III bacteriocins in Group 1 included: enterolysin A, propionicin SM1, and unknown bacteriocin VI. In contrast, phylogenetic Group 2 included only the class II bacteriocin, lactococcin 972.

Interestingly, the 17 Class III enterolysin A-related sequences occurring in Group 1 could be grouped into three subclades. The first and second branches included sequences derived from E. hirae strains C7, MP1-1, MP1-2, MP1-4, MP1-5, DMW1-1, while the third branch included enterolysins A from E. faecalis strains GT3-2, ST1-20, MP8-1, RD1-1, MP5-1, MP9-10, and B9. The alignment of enterolysin A sequences within each branch (Supplementary Figures S1-S3) shows high similarity among them, although they have few conserved amino acids compared to the enterolysin A reference sequences (Supplementary Figure S4).

The alignment of the other bacteriocin sequences with reference sequences was performed (Supplementary Figures S5-S10). Among identities found were conserved motifs such as YGN and cysteine residues (all class IIa bacteriocins can be found in Supplementary Figure S6), and GxxxG or AxxxA motifs among class IIb and circular bacteriocin members (Supplementary Figures S7 and S8). 


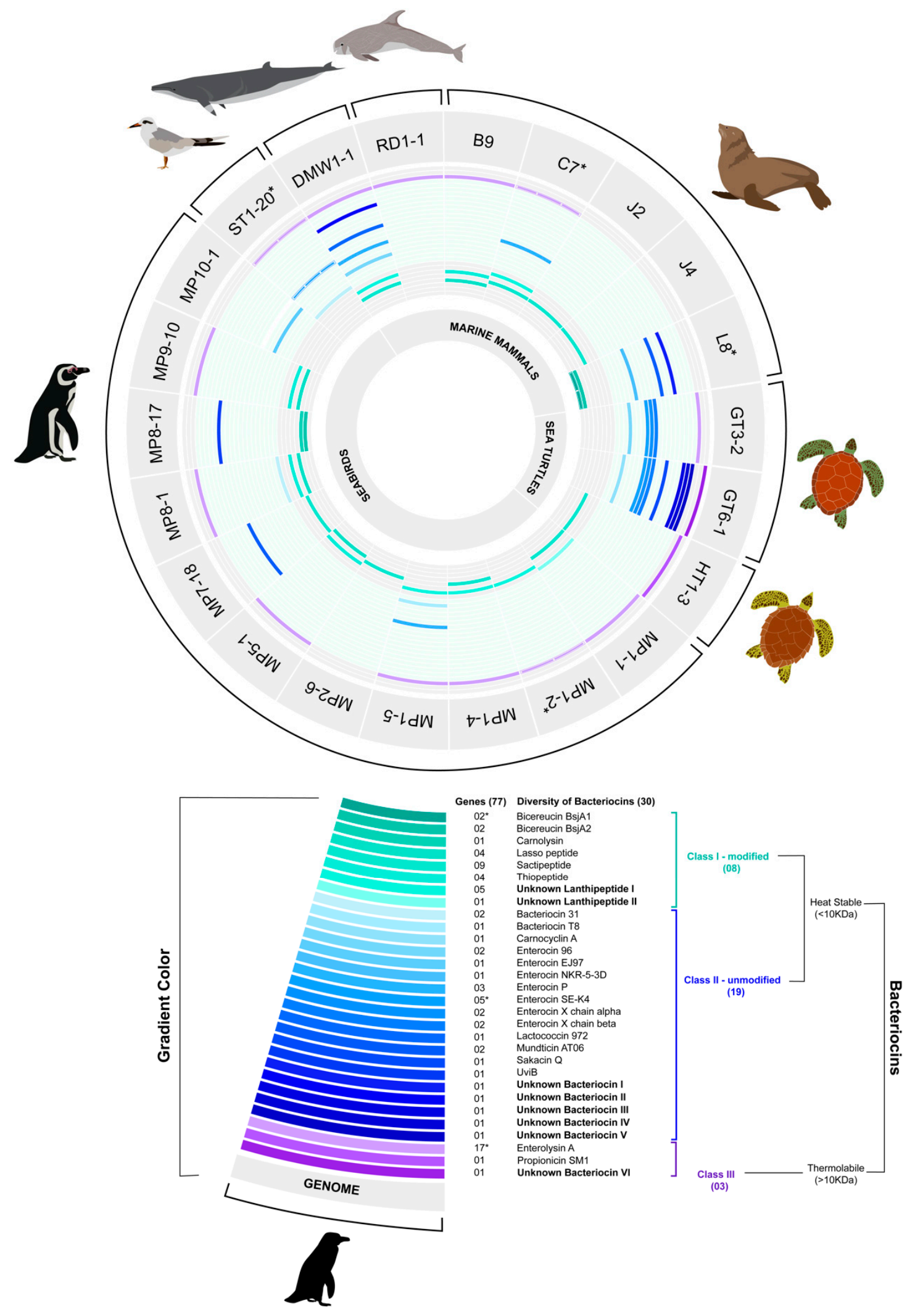

Figure 1. Biosynthetic bacteriocins genes were found within 22 Enterococcus spp. genomes from wild marine animals. The Enterococcus genomes are represented in the external circle (grey). Diversity of bacteriocin genes within 22 Enterococcus spp. genomes are represented by color gradients: Class I (green gradient) and Class II (blue gradient), and Class III (purple). * Genomes showing duplicated bacteriocin genes (rectangles indicate the number of these genes). The illustration was designed using a D3 and Adobe Illustrator. 


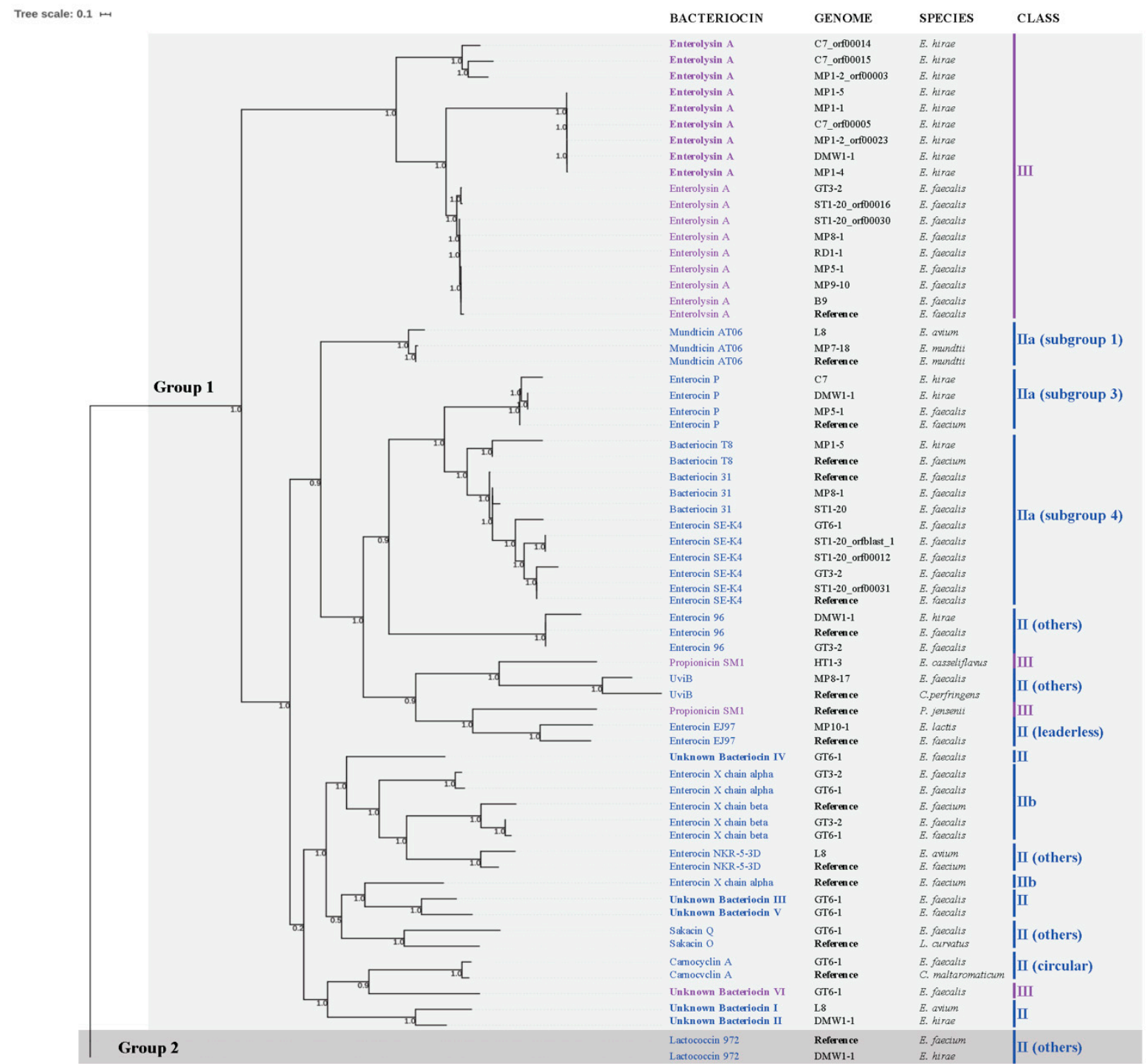

Figure 2. The phylogenetic relationships among bacteriocins (Class II and III) predicted for wild marine animals-associated enterococci genomes. The different groups are represented by grey colors (light grey: Group 1 and dark grey: Group 2). Class II is represented in blue and class III in purple (bold purple are enterolysins A from E. hirae, and regular purple are enterolysins A from E. faecalis). Unknown bacteriocins are highlighted in bold blue (I, II, III, IV, and V) and bold purple (VI).

New putative bacteriocins I, II, and VI showed greater similarity to carnocyclin A, while the unknown bacteriocins III, IV and V were more closely related to enterocin X chain alpha $(\mathrm{X} \alpha)$ (Figure 2). Alignment of unknown bacteriocins with carnocyclin A and Enterocin X $\alpha$ reference sequences allowed detection of conserved amino acid residues and motifs such as GxxxG or AxxxA (Figure 3). Putative novel bacteriocins I, II, VI and carnocyclin A showed only $1.3 \%$ overall amino acid sequence identity (Figure $3 \mathrm{~A}$ ), whereas bacteriocins I and II share $55.22 \%$ identity between them (Figure 3B). Putative bacteriocins III, IV, and V, which were closely related to enterocin $X \alpha$, have $9.2 \%$ overall amino acid sequence identity (Figure 3C); and bacteriocins III and V share $43.4 \%$ identity between them (Figure 3D). Structural modeling of these putative class II and III bacteriocins using the I-TASSER [62] package to build models using a combination of fragment and ab initio model building [63] is shown in Figure 4. Insights into structural features are important for the biosynthesis, mode of action, and biological activity of bacteriocins. The molecular models are in agreement with the expected protein folds (mostly alpha-helices with coil regions). Likewise, the most divergent model (Bacteriocin VI) is also isolated in its group in the phylogenetic reconstruction, supporting its uniqueness among other unknown bacteriocins. 
GENOME

Reference (Bagel: 148.1)

E. faecalis GT6-1

E. avium L8

E. hirae DMW1-1

\section{Reference (Bagel: 148.1)}

E. faecalis GT6-1

E. avium $\mathrm{L} 8$

E. hirae DMW1-1

\section{Reference (Bagel: 148.1)}

E. faecalis GT6-1

E. avium L8

E. hirae DMW1-1

\section{Reference (Bagel: 148.1)}

E. faecalis GT6-1

E. avium L8

E. hirae DMW1-1

\section{BACTERIOCIN}

Carnocyclin A

Unknow Bacteriocin VI

Unknow Bacteriocin I

Unknow Bacteriocin II

\section{Consensus}

Carnocyclin A

Unknow Bacteriocin VI

Unknow Bacteriocin I

Unknow Bacteriocin II

\section{Consensus}

Carnocyclin A

Unknow Bacteriocin VI

Unknow Bacteriocin I

Unknow Bacteriocin I

\section{Consensus}

Carnocyclin A

Unknow Bacteriocin VI

Unknow Bacteriocin I

Unknow Bacteriocin I

Consensus

\section{AA SEQUENCE}

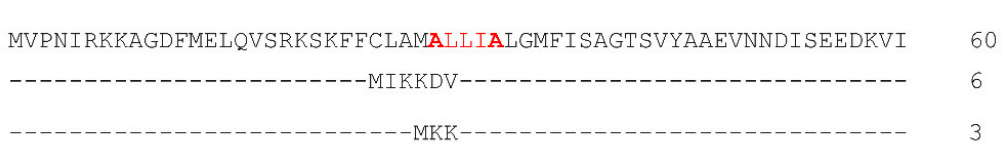

-

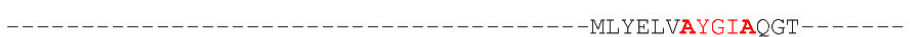

LDNIDVNSFYSDANKGLNEFFSKAVSANPINGKLALNEIGAKDMFGEGIEYEAVVSFIEF -$$
. \therefore
$$

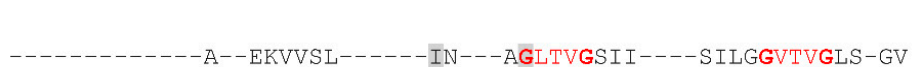

FNSDNNFNELGRFEFRDSLKTLAQGNLPTOTRAGGALAKCAVEWAK---NTFGVGISVAD ---1----WLDSKTKAC------INGQAGGMLAGSPGGLGGI I IGGIGGAIAGGC -------------HLSNNTKAC------INGQLGGMLTGSVGGIGGI ILGGIAGAIAGGC

. $\quad: \quad *: \quad * \quad . \quad \cdot \quad .:$.

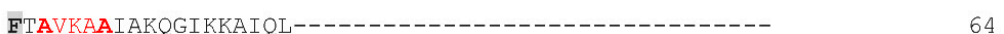

FKSV---LNTYGYAKAAAWLAGKVASSTGRKAAAVLTLVWTAMTCAPIEAE

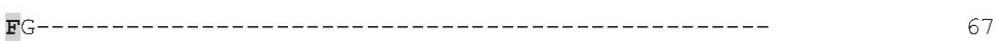

FN- 1

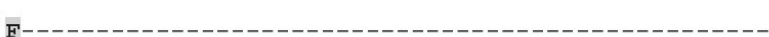

Figure 3. Cont. 
B)

\section{GENOME}

E. avium $\mathrm{L} 8$

E. hirae DMW1-1

\section{BACTERIOCIN}

Unknow Bacteriocin I

Unknow Bacteriocin II

Consensus

\section{AA SEQUENCE}

MIKKDVLKKVDLKKVIGGGGASGTWLDSKTKACINGQAGGMLAGSPGGLGGI I IGGIGGAIAGGCFG

---MKKLTAEEMKQVVGG----RVHLSNNTKACINGQLGGMLTGSVGGIGGI I LGGIAGAIAGGCFN

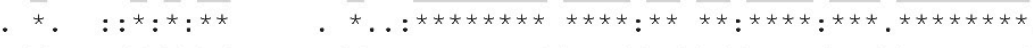
------L-----K-V-GG-------L---TKACINGQ-GGML-GS-GG-GGII-GGI-GAIAGGCF-

\section{C)}

\section{GENOME}

\section{Reference (Bagel: 96.2)}

E. faecalis GT6-1

E. faecalis GT6-1

E. faecalis GT6-1

\section{BACTERIOCIN}

Enterocin $X$ chain alpha

Unknow Bacteriocin III

Unknow Bacteriocin IV

Unknow Bacteriocin V

Consensus

\section{AA SEQUENCE}

MONVKEVSVKEMKOI I GGSNDSL---------WYGVGQFMGKQANCI TNHPVKHMI I PGYCLSKILG-------------- 58 MENFKELTVKEMQKISGGGWQTMSFTPNMECWNGIL----KTGNCRVKWDVVANQAVNNVTSAMIGGFGRGR-------- 68 MTKFKELTVQEMKQISGGKHGKPIYFKDLP-WA-------QQKCILSVA--GGALIGTTTGGPLGALIGAGSQAWGCL- 68 MQNMKELTAKDTQQINGGGWSTPPGLSNIECKNGHL----AVGNCRAKWGDISNGLVNQLVSCAVNGMYGGRCKQPGKFY 76

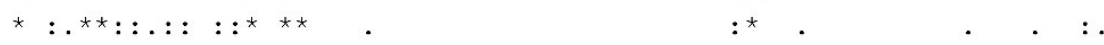
M-- KE--------I-GG---------

\section{D)}

\section{GENOME}

E. faecalis GT6-1

E. faecalis GT6-1

\section{BACTERIOCIN}

Unknow Bacteriocin III

Unknow Bacteriocin V

\section{AA SEQUENCE}

MENFKELTVKEMQKISGGGWQTMSFTPNMECWNGILKTGNCRVKWDVVANQAVNNVTSAMIGGFGRGR-------- 68 MQNMKELTAKDTQQINGGGWSTPPGLSNIECKNGHLAVGNCRAKWGDISNGLVNQLVSCAVNGMYGGRCKQPGKFY 76

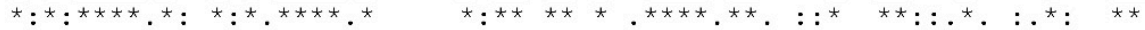
M-N-KELT-K--Q-I-GGGW-T-----N-EC-NG-L--GNCR-KW----N--VN---S----G---GR--------

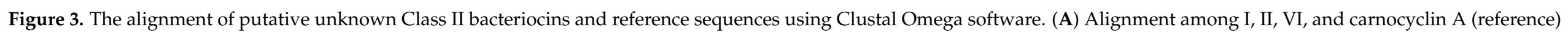

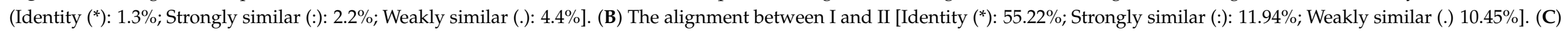

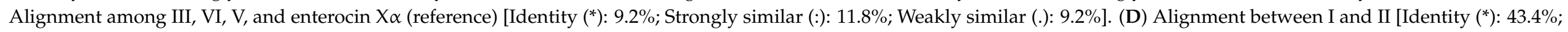

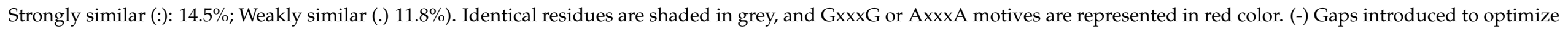

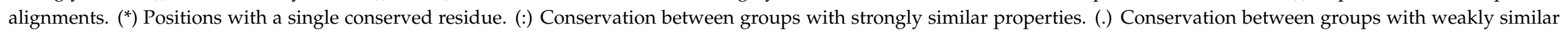
properties. 


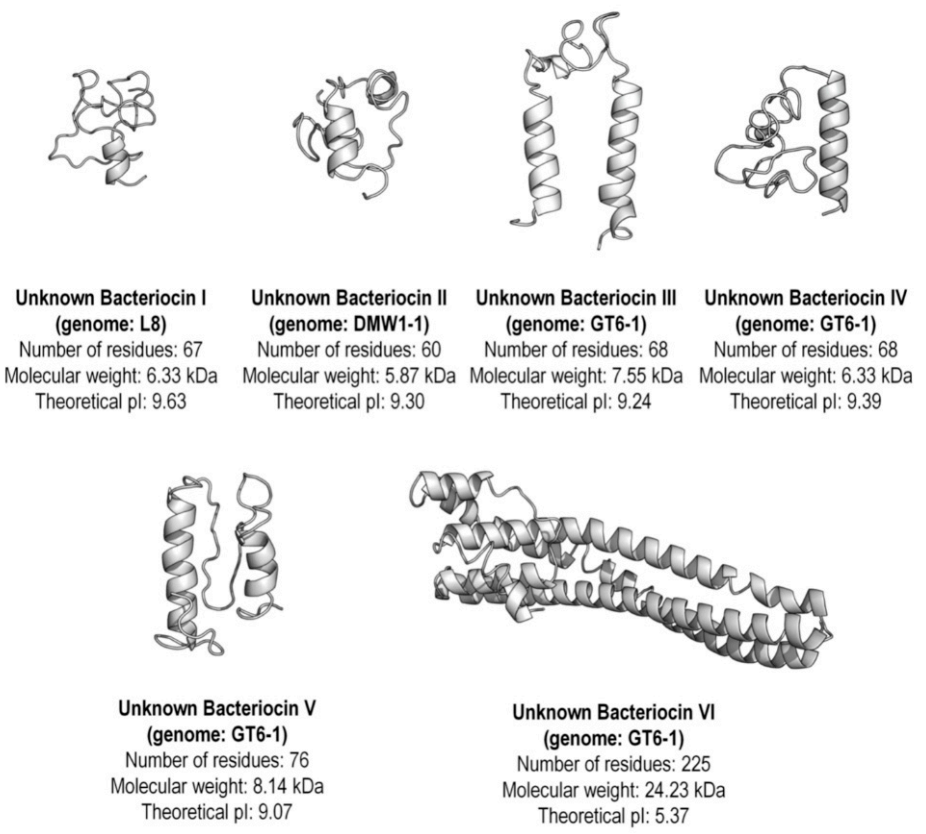

Figure 4. The structural modeling of unknown Class II enterococcal bacteriocins from wild marine animals.

\subsection{Detection of Genes Associated with Enhanced Enterococcal Virulence}

Among the 22 genomes evaluated, E. avium (L8) and E. mundtii (MP7-18) were found to be devoid of determinants that have mainly been identified in E. faecalis and E. faecium strains associated with enhanced virulence (Figure 5A,B). All other enterococci strains possessed at least one potential virulence-associated trait (Figure 5B). As expected, these were most common in E. faecalis, where they have been most thoroughly studied. Some of these traits are encoded within the core genomes $[25,26]$. The unique E. lactis harbored efaAfm and $a \mathrm{~cm}$ genes, while all $E$. faecalis contained several genes associated with adhesion (ace, efa Afs), biofilm production (ebp A, ebp B and $e b p \mathrm{C})$, proteases (gelE and $s r t \mathrm{~A})$, protection against oxidative stress (tpx), and quorum sensing and sex pheromone (cad, camE, $c \mathrm{CF} 10$, $c \mathrm{OB} 1$, and $\left.f_{s} r \mathrm{~B}\right)$. Enterococcus faecalis genomes varied in the presence of hyaluronidase genes (hylA and hylB) and adhesion-associated gene (ElrA).

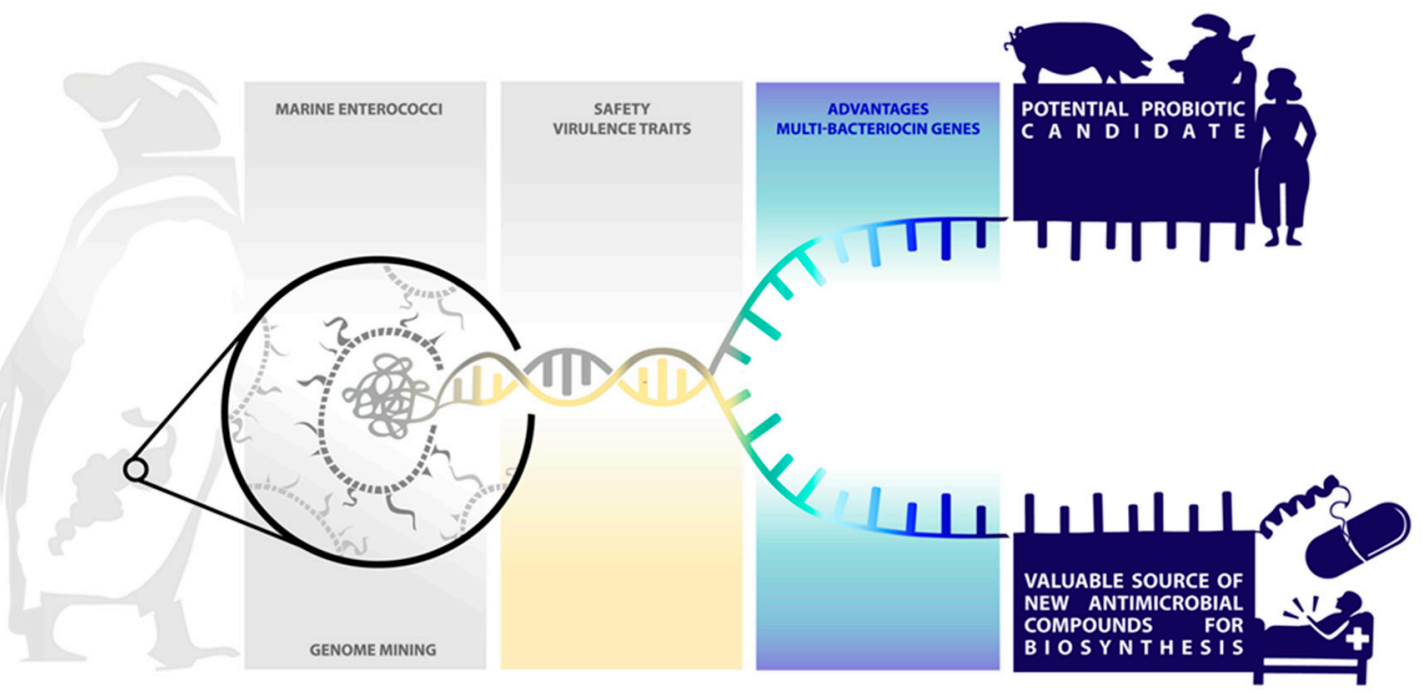

(A)

Figure 5. Cont. 


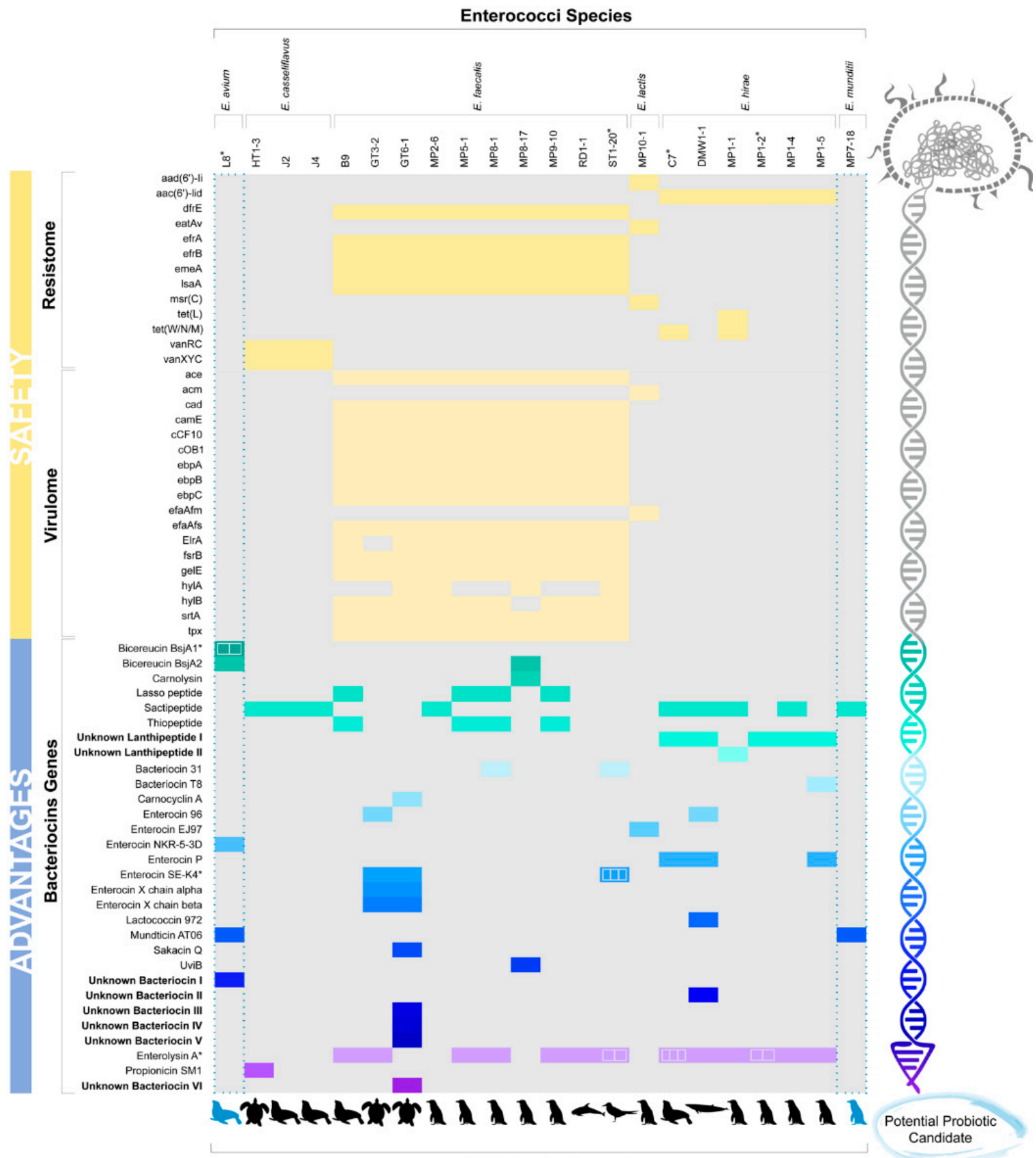

Wild Marine Animals

(B)

Figure 5. Wild marine animals-associated enterococci might represent a potentially valuable source of new compounds for biotechnological application and generation of new drug leads and potential probiotic application. (A) Scheme showing the main marine enterococci biotechnological applications suggested in this study. (B) Virulence markers analysis revealed potential probiotic enterococci from wild marine animals. Determinants of resistance (light yellow) and virulence (dark yellow) were associated with the results of in silico screening by bacteriocins (green, blue, and purple colors). ${ }^{*}$ Genomes showing duplicated bacteriocin genes (rectangles are representing the number of these genes). Blue dash representing the potential probiotic candidate strains (L8 and MP7-18). The illustration was designed using D3, R software, and Adobe Illustrator. 
Resistome analysis (Figure 5B) revealed that all E. casseliflavus genomes $(n=3)$ possessed genes related to low-level vancomycin resistance (van RC and vanXYC), as expected since these are part of the core genome for that species [64]. All E. faecalis genomes $(n=10)$ contained genes within the core genomes [26] conferring resistance to trimethoprim ( $d f \mathrm{rE})$; to macrolide, fluoroquinolone, and rifamycin (efr $\mathrm{A}$ and efr $\mathrm{B}$ ); to pleuromutilin, lincosamide, and streptogramin $(l s a \mathrm{~A})$; and have a multidrug and toxic compound extrusion transporter (emeA). On the other hand, the unique E. lactis genome possessed genes related to the resistance to aminoglycosides $\left(\operatorname{aac}\left(6^{\prime}\right)\right.$-Ii); to macrolide, lincosamide, streptogramin, tetracycline, oxazolidinone, phenicol, pleuromutilin (eat Av); and to macrolide, lincosamide, streptogramin $(\mathrm{msrC})$. In addition, E. hirae genomes harbored genes related to aminoglycoside $\left(\operatorname{acc}\left(6^{\prime}\right)-\mathrm{Iid} ; n=6\right)$, and tetracycline $[\operatorname{tet}(\mathrm{W} / \mathrm{N} / \mathrm{M}), n=2 ;$ tet $(\mathrm{L}) ; n=1]$ resistance.

\section{Discussion}

Microbes associated with marine animals from remote ecologies may be important sources for new tools to manage human and/or microbial interactions. In this study, we explored Enterococcus strains from the microbiota of wild sea birds, sea turtles, and marine mammals that range from the Antarctic to the coast of Brazil to identify potentially novel BGCs. These prospective BCGs were found in generalist species E. faecalis, as well as less common and less studied species, including E. avium, E. casseliflavus, E. hirae, E. lactis, and E. mundtii.

Putative bacteriocin genes were present in all enterococcal strains investigated, highlighting the competitive nature of the gut niche. Bacteriocin-encoding genes are known to be widely disseminated among enterococci species of different origins $[33,54,55]$. However, likely because of the novel environmental source of these strains, we found considerable diversity and novelty (Figure 1), with eight genomes possessing four or more bacteriocin gene clusters. This may be driven by variation in wild marine animal diets along migratory routes, combined with selection pressure for factors to control population structure and niche control in the host gut.

Enterococcal bacteriocins are of interest because of their antimicrobial activities, with activity against different Gram-positive and Gram-negative bacteria, including species of Listeria, Clostridium, Staphylococcus, Streptococcus, Cutibacterium, Pseudomonas, and Salmonella $[6,33,34,65]$. Enterocins have also been described as effective agents against antibiotic-resistant bacteria such as vancomycin-resistant enterococci (VRE) and methicillinresistant Staphylococcus aureus (MRSA) [35,46]. Furthermore, antiviral activities have been reported against herpes simplex viruses (HSV-1 and HSV-2), polio virus (PV3), measles virus, and influenza virus $[41,66]$. Immunomodulatory and anticancer properties of enterocins have not been widely explored but may also be of potential interest [67-69].

In this study, we identified known bacteriocins, natural variants of known bacteriocins, and potentially new bacteriocins distributed among different enterococcal species. The potency and spectrum of bacteriocins against important pathogens vary according to the peptide subclass $[34,35,66,70]$. Class I bacteriocins were identified in our in silico screening, with sactipeptides, new lanthipeptides I, lasso peptides, and thiopeptides being found in high numbers (Figure 1). Sactipeptides are produced mainly by Gram-positive organisms, and according to previous studies, the sactipeptides from Bacillus subtilis (subtilisin A) and Bacillus thuringiensis (Thuricin CD) have broad and narrow antimicrobial activity spectra, respectively [34,71]. A previous study also identified sactipeptide BGC in Enterococcus mudtii QU25 [36], similar to one found in this study. Lantibiotics and thiopeptides are most active against Gram-positive pathogens, including MRSA, VRE, and Clostridium difficile [23,34]. In contrast, most lasso peptides show activity against Gram-negative pathogens, e.g., bacteriocin MccJ25, which is active against some strains of Escherichia coli and Salmonella spp. [34].

The present study provides further evidence of the significant biodiversity of BGCs for class II, 19 bacteriocins, including five new putative bacteriocins (Figures 1 and 2; Supplementary Table S4). Class II bacteriocins are of special interest as potential therapeutic 
agents and have been proposed on a larger scale production, whether in the food industry or in human health and veterinary medicine [72-74]. Because they consist of unmodified peptides, they do not require enzymes for their maturation and are small structures, less than $10 \mathrm{kDa}[36,73]$, that may subject to low-cost production than other classes by chemical synthesis [73]. Complementing the recombinant technologies, chemical synthesis of bacteriocins may allow further molecular engineering for enhanced potency, improved pharmacological properties, increased stability and modified spectra of activity [73]. Class II bacteriocins and analogs thereof have been successfully prepared by chemical syntheses, such as aureocin A53 (AucA), durancin A5-11, enterocin CRL35, lactococcin MMFII, leucocin A, pediocin PA-1, curvacin A, lacticin Q (LnqQ), mesentericin Y105, and sakacin $\mathrm{P}$ [72-74].

In general, the class II bacteriocins are most active against Gram-positive pathogens, especially the class IIa bacteriocins, which are active against L. monocytogenes and other Gram-positive pathogens [33,34,72,75]. Enterocin SE-K4 and enterocin P were the most frequent class II bacteriocins in this study (Figure 1). Enterocin SE-K4 has been reported to exhibit antimicrobial activity against Gram-positive bacteria, B. subtilis, Clostridium beijerinckii, E. faecium, E. faecalis, and L. monocytogenes [40]. In contrast, enterocin P has a broad antimicrobial spectrum that includes activity against food-borne pathogens, C. botulinum, C. perfringens, L. monocytogenes, and S. aureus [64], as well as clinical strains, L. monocytogenes, Salmonella (S.) typhi, Salmonella paratyphi C, Shigella dysenteriae, vancomycin-resistant enterococci (VRE), and carbapenem-resistant Pseudomonas aeruginosa [75,76].

It is also important to highlight that class III bacteriocins were most common and widely distributed from wild marine animals and also included the unknown bacteriocin VI (Figure 1). Furthermore, three different enterolysin A sequences were verified among enterococci species, with two of them from $E$. hirae genomes that are reported for the first time in this species. Enterolysin A is a cell wall-degrading bacteriocin first reported to be produced by E. faecalis isolated from fish in Iceland [77]. Despite class III bacteriocins are large proteins (more than $10 \mathrm{kDa}$ ) and complex produced by chemical approaches [61], enterolysin A have been reported as broad-spectrum activity against pathogenic and nonpathogenic bacteria; acting on cleave the peptide bonds within the stem peptide as well as in the interpeptide bridge of Gram-positive bacterial cell walls $[33,78]$.

In addition to bacteriocins, a wide variety of novel gene clusters encoding putative terpenes, NRPs, polyketides, and other active compounds have been uncovered by in silico analysis, creating new opportunities for drug development $[23,24,49,79]$. NRPs and terpenes have been reported with activity against several antibiotic-resistant strains [80-85]. A small library of predicted NRP peptides was chemically synthesized, based on the primary sequence of NRP clusters in the human microbiome, and a potent anti-MRSA (methicillin-resistant Staphylococcus aureus) peptide with a new mechanism of action, named humimycin, was identified [80]. The antitubercular agent levesquamide is a new polyketidenonribosomal peptide (PK-NRP) hybrid of a marine natural product (BGC) identified and isolated from Streptomyces sp. [84]. Furthermore, the antibacterial activity of 33 free terpenes commonly found in essential oils was evaluated, with 16 compounds showing antimicrobial activity, including eugenol, which exhibited rapid bactericidal action against Salmonella enterica serovar Typhimurium. Further, terpineol showed excellent bactericidal activity against $S$. aureus strains, and carveol, citronellol, and geraniol were rapidly bactericidal for E. coli [81]. In this study, we also found terpene biosynthesis-related clusters in E. casseliflavus, E. hirae, and E. mundtii species. Terpenes are secondary metabolites found in plants, bacteria, and fungi and have been shown to act as antibiotics, hormones, flavor or odor constituents, and pigments [86-88]. Beukers and collaborators [89] also identified putative genes or operons involved in terpene synthesis in E. hirae, E. villorum, E. gallinarum, E. durans, and E. casseliflavus strains isolated from bovine feces. The role of terpenes in enterococcal biology, including their possible involvement as bacteriocins, remains unclear [89]. 
Previous studies have examined the probiotic potential of enterococci from the marine environment $[43,90,91]$. Marine probiont strains have been used in finfish aquaculture due to their health beneficial effect and low potential to transfer antibiotic resistance genes to pathogens through horizontal gene transfer [92]. The potential of 13 enterococci isolated from wild seals was evaluated in a previous study from our group, and five (36.46\%) showed activity against L. monocytogenes ATCC 35152 in the double-agar layer test, and one of them should be a good candidate for probiotic application [43]. In the present study, genome screening for bacteriocins highlighted potential probiotic enterococcal strains lacking known virulence or resistance traits (Figure 5A, B). In particular, the E. avium (L8) genome contained gene clusters for bicereucin BsjA1 and BsjA2, enterocin NKR-5-3D, mundticin AT06, and unknown bacteriocin I; and the E. mundtii genome (MP7-18) encoded sacpeptide and mundticin AT06 variants. Members of the genus Enterococcus have not yet obtained the status of generally recognized as safe (GRAS), although some are already being used as probiotics and in the production of animal food additives to prevent diseases or to improve growth $[93,94]$. New regulations for probiotics that distinguish between safe and potentially harmful strains are needed [35]. The application of genomic approaches in probiotic research would improve the understanding of the molecular mechanisms that endow the genera with safe and favorable traits [95].

Host-associated microbes are a rich source of factors that regulate community structure in a manner compatible with host health $[96,97]$. Our findings show a considerable novelty of biosynthetic pathways to be found by exploring the genomes of wild marine-animalsassociated microbes in remote ecologies with the potential to shape host-associated microbial population structures. The novel compounds and natural bacteriocin variants were discovered to provide the first leads for deriving new approaches for managing humanmicrobe interactions in health and disease. Besides, this data will inform and broaden the limits of known structural variation, knowledge of how structure relates to activity, and synthetic biology. In this context, as a perspective for further studies, the data generated here may be associated with recombinant technologies, chemical synthesis, molecular engineering, and other strategies to increase the biological potency, stability, and pharmacological properties in order to guarantee or modify the antimicrobial activity. Therefore, our results may contribute to promote the future development of bacteriocin-based drugs for potential use in managing animal and human health and as food preservatives.

\section{Materials and Methods}

\subsection{Bacterial Strains}

Twenty-two enterococci strains previously described $[26,98,99]$ were evaluated in the present study. Briefly, the collection includes Enterococcus species isolated from fecal samples (cloacal/anal swabs or intestinal content) collected from 17 wild marine animals. These animals, including sea turtles $(n=3)$, seabirds $(n=8)$, and marine mammals $(n=6)$, were found along the North Coast of Rio Grande do Sul, Southern Brazil, from Torres Beach $\left(29^{\circ} 21^{\prime} 32.2^{\prime \prime}\right.$ S; $\left.49^{\circ} 44^{\prime} 10.3^{\prime \prime} \mathrm{W}\right)$ to Dunas Altas Beach, Palmares do Sul $\left(30^{\circ} 23^{\prime} 58.75^{\prime \prime}\right.$ S; $50^{\circ} 17^{\prime} 24.73^{\prime \prime} \mathrm{W}$ ), between July 2012 and April 2014 (Table 1). The enterococci collection was stored frozen at $-20{ }^{\circ} \mathrm{C}$ in skim milk supplemented with $20 \%$ glycerol, and cultures were routinely grown in brain heart infusion (BHI) at $37^{\circ} \mathrm{C}$ for $18 \mathrm{~h}$.

\subsection{Genomic DNA Preparation, High-Throughput Sequencing, Assembly, and Annotation}

The Enterococcus spp. strains were grown in BHI at $37^{\circ} \mathrm{C}$ for $18 \mathrm{~h}$. Genomic DNA was extracted using a commercial kit (QIAGEN DNeasy Blood \& Tissue Kit, San Luis, MO, USA). Manufacturer instructions were followed with minor modification, namely, the addition of $50 \mu \mathrm{L}$ of lysozyme $(50 \mathrm{mg} / \mathrm{mL})$ and $10 \mu \mathrm{L}$ mutanolysin $(2500 \mathrm{U} / \mathrm{mL}$, SigmaAldrich, Germantown, MD, USA) for $30 \mathrm{~min}$ at $37^{\circ} \mathrm{C}$ before the addition of $20 \mu \mathrm{L}$ proteinase $\mathrm{K}(20 \mathrm{mg} / \mathrm{mL})$. Extracted DNA was quantified using the Qubit double-stranded DNA (dsDNA) high-sensitivity (HS) assay kit (Life Technologies, Carlsbad, CA, USA). Libraries for genome sequencing were prepared using the Nextera XT DNA kit and index primers 
(Illumina), and reads were generated by HiSeq/MiSeq reagent kit version 2 with 250 cycles on an Illumina HiSeq/Miseq platforms. Reads were subjected to de novo assembly using the CLC genomics workbench v8.0.3, and open reading frames (ORFs) were predicted using the NCBI Prokaryotic Annotation Pipeline-PGAP [100]. The enterococci species assignment was confirmed by pairwise comparison of their average nucleotide identity (ANI) using JSpeciesWS [101] and the following reference genomes available from GenBank (https: / / www.ncbi.nlm.nih.gov (accessed on 15 December 2020): Enterococcus avium ATCC 14025; Enterococcus casseliflavus ATCC 12755; Enterococcus faecalis ATCC 19433; Enterococcus faecium Aus0004 (Clade A1); Enterococcus faecium EnGen0007 (Clade A2); Enterococcus faecium Com12 (Clade B); Enterococcus hirae ATCC 9790; Enterococcus lactis KCTC 21015; Enterococcus mundtii ATCC 882. The GenBank accession number of reference strains is presented in Supplementary Table S2.

\subsection{Genome Mining for Antimicrobial Compounds}

Putative biosynthetic gene clusters (BGCs) were predicted using antiSMASH (antibiotics and Secondary Metabolite Analysis Shell 5.0) [57] and Bagel4 (bacteriocins and RiPP-Ribosomally synthesized and Post-translationally modified Peptides) [58] using the default parameters. The bacteriocin classification is in accordance with previous proposals for enterococci [33] and lactic acid bacteria [36] that accommodate the novel subclasses that are appearing over the last years, based on the biosynthesis mechanism and biological activity.

\subsection{Phylogenetic Analysis}

Amino acid sequences corresponding to bacteriocin genes (class II and class III) found in this work, along with reference sequences identified by AntiSMASH 5.0 [57] and Bagel4 [58], and Uniprot databases were aligned using MAFFT [102]. Guidance2 [103] was used to filter unreliable positions and generate a mega alignment encompassing 5 alternative alignments for the sequences. The mega alignment was used to infer the evolutionary history of these proteins by using the Maximum Likelihood method, based on the VT model [104]. A discrete Gamma distribution was used to model evolutionary rate differences among sites, and the rate variation model allowed for some sites to be evolutionarily invariable [105]. Significance was assessed via aLRT [106]. All evolutionary analyses were conducted in PhyML 3.0 [107]. Tree visualization and annotation were performed on Interactive Tree Of Life (iTOL) v [108].

\subsection{Molecular Modeling}

The structural modeling of unknown bacteriocins (I, II, III, IV, and VI) was performed using the I-TASSER package $[62,63]$ since they were not suitable for traditional comparative modeling, requiring a combination of fragment and ab initio model building. UCSF Chimera [109] was used to visualize and edit the new bacteriocin structural models. Physico-chemical parameters were calculated with ProtParam [110].

\subsection{Potential Virulence Markers}

The comprehensive antibiotic resistance database (CARD/RGI-2017) [111] and Resfinder 3.2 [112] were used to identify antimicrobial resistance genes with default parameters and identification threshold of $60 \%$ identity over a length of $60 \%$ coverage, respectively. Virulence genes were predicted using VirulenceFinder [113], with a threshold of $85 \%$ identity over a length of $60 \%$.

\subsection{Figures Design}

Figures were designed using D3 (or D3.js, a JavaScript library for visualizing data using web standards) [114], R software (R Development Core Team, 2019) [115], and Adobe Illustrator. 


\section{Conclusions}

Our findings show that there is a considerable novelty to be found through exploring the genomes of host-associated microbes from animals in remote ecologies for biosynthetic pathways with the potential to shape host-associated microbial population structures. The novel compounds and natural bacteriocin variants discovered provide first leads for the derivation of new approaches for managing human-microbe interactions in health and disease.

Supplementary Materials: The following are available online at https:/ /www.mdpi.com/article/10 $.3390 / \mathrm{md} 19060328 / \mathrm{s} 1$, Table S1: Sequencing statistics, genome sizes, fold coverage, G+C content, of the Enterococcus spp. sequenced. Table S2: Reference genomes used to confirm the enterococci species. Table S3: Putative antimicrobial compounds biosynthesis gene clusters (BGCs) data predicted with antiSMASH5 and Bagel4 software. Table S4: Class I, class II, and class III unknown bacteriocins BGCs data that were not previously identified in antiSMASH5 and Bagel4 databases. Table S5: Class II and class III bacteriocin sequences predicted with antiSMASH5 and Bagel4 software. Table S6: Reference sequences from Bagel4 and Uniprot databases. Figure S1: The alignment of putative enterolysin A (class III) sequences (first branch) from E. hirae genomes using Clustal Omega software. Figure S2: The alignment of putative enterolysin A (class III) sequences (second branch) from E. hirae genomes using Clustal Omega software. Figure S3: The alignment of putative enterolysin A (class III) sequences (third branch) from E. faecalis genomes using Clustal Omega software. Figure S4: The alignment of four different enterolysin A (class III) and three different references (Bagel 62.3: E. faecalis LMG 2333; Bagel 63.3: E. faecalis; and Bagel 64.3: Lactobacillus acidophilus) using Clustal Omega software. Figure S5: The alignment of putative propionicin SM1 (class III) and reference sequence using Clustal Omega software. Figure S6: The alignment of putative Class IIa bacteriocins and reference sequences using Clustal Omega software. Figure S7: The alignment of putative class $\mathrm{IIb}$ bacteriocins and reference sequences using Clustal Omega software. Figure S8: The alignment of putative class II circular bacteriocin carnocyclin A and reference sequence using Clustal Omega software. Figure S9: The alignment of putative class II leaderless bacteriocin enterocin EJ97 and reference sequence using Clustal Omega software. Figure S10: The alignment of putative class II other bacteriocins and reference sequences using Clustal Omega software.

Author Contributions: J.P., A.S., M.P.-B. and M.S.G. designed the study. Samples were collected by M.T. The bacteria isolation, extraction, and genome sequencing were performed by J.P. and T.G.S.P. Bioinformatics approaches, analyze of data, and figures were designed by J.P., M.P.-B., R.C.Z.L., I.M.S.C. and R.L.-B. The original draft manuscript was written by J.P., M.P.-B., A.S. and M.S.G. This study was funded and/or supervised by A.S., J.F., P.A.d., A.P.G.F. and M.S.G. All authors have read and agreed to the published version of the manuscript.

Funding: This research was funded by the NIH grant AI083214-Harvard-wide program on antibiotic resistance-, Conselho Nacional de Desenvolvimento Científico e Tecnológico do Brasil, and Coordenação e Aperfeiçoamento de Pessoal de Nível Superior (CAPES) of the Brazilian government (CNPq; 40788/2018-4).

Data Availability Statement: The novel genome sequences were deposited at DDBJ/ENA/GenBank as whole-genome shotgun projects under the accession numbers according to Table S1.

Acknowledgments: The authors would like to thank the Center for Coastal Studies, Limnology and Marine (CECLIMAR) for assistance in collecting samples and to members of the Enteromar Research Group for critical feedback on the manuscript.

Conflicts of Interest: The authors declare no conflict of interest.

\section{References}

1. Wohlleben, W.; Mast, Y.; Stegmann, E.; Ziemert, N. Antibiotic Drug Discovery. Microb. Biotechnol. 2016, 9, 541-548. [CrossRef]

2. Willyard, C. The Drug-Resistant Bacteria that Pose the Greatest Health Threats. Nature 2017, 543, 15. [CrossRef]

3. Tacconelli, E.; Carrara, E.; Savoldi, A.; Harbarth, S.; Mendelson, M.; Monnet, D.L.; Pulcini, C.; Kahlmeter, G.; Kluytmans, J.; Carmeli, Y.; et al. Discovery, Research, and Development of New Antibiotics: The WHO Priority List of Antibiotic-Resistant Bacteria and Tuberculosis. Lancet Infect. Dis. 2018, 18, 318-327. [CrossRef]

4. Buonocore, F. Marine Biotechnology: Developments and Perspectives. J. Aquac. Res. Dev. 2013, 4, 9546. [CrossRef] 
5. Reen, F.J. Emerging Concepts Cromising New Horizons for Marine Biodiscovery and Synthetic Biology. Mar. Drugs 2015, 31, 2924-2954. [CrossRef] [PubMed]

6. Calle, F. Marine Microbiome as Source of Natural Products. Microb. Biotechnol. 2017, 10, 1293-1296. [CrossRef] [PubMed]

7. Smith, D. Discovery Pipelines for Marine Resources: An Ocean of Opportunity for Biotechnology? World J. Microbiol. Biotechnol. 2019, 8, 1293-1296. [CrossRef] [PubMed]

8. Desriac, F. Bacteriocin as Weapons in the Marine Animal-Associated Bacteria Warfare: Inventory and Potential Applications as an Aquaculture Probiotic. Mar. Drugs 2010, 25, 1153-1177. [CrossRef] [PubMed]

9. Debbab, A.; Aly, A.H.; Lin, W.H.; Proksch, P. Bioactive Compounds from Marine Bacteria and Fungi. Microb. Biotechnol. 2010, 20, 544-563. [CrossRef] [PubMed]

10. Deer, T.R.; Pope, J.E.; Hanes, M.C.; McDowell, G.C. Intrathecal Therapy for Chronic Pain: A Review of Morphine and Ziconotide as Firstline Options. Pain Med. 2019, 20, 784-798. [CrossRef] [PubMed]

11. Fujisawa, Y.; Fujimura, T.; Matsushita, S.; Yamamoto, Y.; Uchi, H.; Otsuka, A.; Funakoshi, T.; Miyagi, T.; Hata, H.; Gosho, M.; et al. The Efficacy of Eribulin Mesylate for Patients with Cutaneous Angiosarcoma Previously Treated with Taxane: A Multicentre Prospective Observational Study. Br. J. Dermatol. 2020, 183, 831-839. [CrossRef] [PubMed]

12. Luesch, H.; Moore, R.E.; Paul, V.J.; Mooberry, S.L.; Corbett, T.H. Isolation of Dolastatin 10 from the Marine Cyanobacterium Symploca Species VP642 and Total Stereochemistry and Biological Evaluation of Its Analogue Symplostatin 1. J. Nat. Prod. 2001, 64, 907-910. [CrossRef]

13. Luesch, H.; Chanda, S.K.; Raya, R.M.; DeJesus, P.D.; Orth, A.P.; Walker, J.R.; Izpisúa Belmonte, J.C.; Schultz, P.G. A Functional Genomics Approach to the Mode of Action of Apratoxin A. Nat. Chem. Biol. 2006, 2, 158-167. [CrossRef]

14. Galonić, D.P.; Barr, E.W.; Walsh, C.T.; Bollinger, J.M.; Krebs, C. Two Interconverting Fe (IV) Intermediates in Aliphatic Chlorination by the Halogenase CytC3. Nat. Chem. Biol. 2007, 3, 113-116. [CrossRef]

15. Liao, L.; Lee, J.-H.; You, M.; Choi, T.J.; Park, W.; Lee, S.K.; Oh, D.-C.; Oh, K.-B.; Shin, J. Penicillipyrones A and B, Meroterpenoids from a Marine-Derived Penicillium Sp. Fungus. J. Nat. Prod. 2014, 77, 406-410. [CrossRef]

16. Mayer, A.M.S.; Guerrero, A.J.; Rodríguez, A.D.; Taglialatela-Scafati, O.; Nakamura, F.; Fusetani, N. Marine Pharmacology in 2014-2015: Marine Compounds with Antibacterial, Antidiabetic, Antifungal, Anti-Inflammatory, Antiprotozoal, Antituberculosis, Antiviral, and Anthelmintic Activities; Affecting the Immune and Nervous Systems, and Other Miscellaneous Mechanisms of Action. Mar. Drugs 2019, 18, 5.

17. Kamada, T.; Vairappan, C.S. New Laurene-Type Sesquiterpene from Bornean Laurencia nangii. Nat. Prod. Commun. 2015, 10, 843-844. [CrossRef]

18. Piao, M.; Hewage, S.; Han, X.; Kang, K.; Kang, H.; Lee, N.; Hyun, J. Protective Effect of Diphlorethohydroxycarmalol against Ultraviolet B Radiation-Induced DNA Damage by Inducing the Nucleotide Excision Repair System in HaCaT Human Keratinocytes. Mar. Drugs 2015, 13, 5629-5641. [CrossRef] [PubMed]

19. Tsueng, G.; Teisan, S.; Lam, K.S. Defined Salt Formulations for the Growth of Salinispora tropica Strain NPS21184 and the Production of Salinosporamide A (NPI-0052) and Related Analogs. Appl. Microbiol. Biotechnol. 2008, 78, 827-832. [CrossRef] [PubMed]

20. Freundlich, J.S.; Lalgondar, M.; Wei, J.-R.; Swanson, S.; Sorensen, E.J.; Rubin, E.J.; Sacchettini, J.C. The Abyssomicin C Family as in Vitro Inhibitors of Mycobacterium tuberculosis. Tuberculosis 2010, 90, 298-300. [CrossRef] [PubMed]

21. Wyche, T.P.; Piotrowski, J.S.; Hou, Y.; Braun, D.; Deshpande, R.; McIlwain, S.; Ong, I.M.; Myers, C.L.; Guzei, I.A.; Westler, W.M.; et al. Forazoline A: Marine-Derived Polyketide with Antifungal In Vivo Efficacy. Angew. Chem. Int. Ed. 2014, 53, 11583-11586. [CrossRef] [PubMed]

22. Liu, D.; Yang, A.; Wu, C.; Guo, P.; Proksch, P.; Lin, W. Lipid-Lowering Effects of Farnesylquinone and Related Analogues from the Marine-Derived Streptomyces nitrosporeus. Bioorg. Med. Chem. Lett. 2014, 24, 5288-5293. [CrossRef]

23. Donia, M.S.; Cimermancic, P.; Schulze, C.J.; Wieland Brown, L.C.; Martin, J.; Mitreva, M.; Clardy, J.; Linington, R.G.; Fischbach, M.A. A Systematic Analysis of Biosynthetic Gene Clusters in the Human Microbiome Reveals a Common Family of Antibiotics. Cell 2014, 158, 1402-1414. [CrossRef] [PubMed]

24. Wang, L.; Ravichandran, V.; Yin, Y.; Yin, J.; Zhang, Y. Natural Products from Mammalian Gut Microbiota. Trends Biotechnol. 2019, 37, 492-504. [CrossRef] [PubMed]

25. Lebreton, F.; Manson, A.L.; Saavedra, J.T.; Straub, T.J.; Earl, A.M.; Gilmore, M.S. Tracing the Enterococci from Paleozoic Origins to the Hospital. Cell 2017, 169, 849-861. [CrossRef]

26. Prichula, J.; Van Tyne, D.; Schwartzman, J.; Sant'Anna, F.H.; Pereira, R.I.; da Cunha, G.R.; Tavares, M.; Lebreton, F.; Frazzon, J.; d'Azevedo, P.A.; et al. Enterococci from Wild Magellanic Penguins (Spheniscus magellanicus) as an Indicator of Marine Ecosystem Health and Human Impact. Appl. Environ. Microbiol. 2020, 86, e01662-20. [CrossRef]

27. Lebreton, F.; van Schaik, W.; Manson McGuire, A.; Godfrey, P.; Griggs, A.; Mazumdar, V.; Corander, J.; Cheng, L.; Saif, S.; Young, S.; et al. Emergence of Epidemic Multidrug-Resistant Enterococcus Faecium from Animal and Commensal Strains. mBio 2013, 4, e00534-13. [CrossRef] [PubMed]

28. Raven, K.E.; Reuter, S.; Reynolds, R.; Brodrick, H.J.; Russell, J.E.; Török, M.E.; Parkhill, J.; Peacock, S.J. A Decade of Genomic History for Healthcare-Associated Enterococcus faecium in the United Kingdom and Ireland. Genome Res. 2016, 26, 1388-1396. [CrossRef] [PubMed] 
29. Raven, K.E.; Reuter, S.; Gouliouris, T.; Reynolds, R.; Russell, J.E.; Brown, N.M.; Török, M.E.; Parkhill, J.; Peacock, S.J. GenomeBased Characterization of Hospital-Adapted Enterococcus faecalis Lineages. Nat. Microbiol. 2016, 1, 15033. [CrossRef]

30. Fiore, E.; Van Tyne, D.; Gilmore, M.S. Pathogenicity of Enterococci. Microbiol. Spect. 2019, 7, 378-397.

31. Brock, T.D.; Peacher, B.; Pierson, D. Survey of the Bacteriocines of Enterococci. J. Bacteriol. 1963, 86, 702-707. [CrossRef]

32. Nes, I.F.; Diep, D.B.; Holo, H. Bacteriocin Diversity in Streptococcus and Enterococcus. J. Bacteriol. 2007, 189, 1189-1198. [CrossRef]

33. Ness, I.F.; Diep, D.B.; Ike, Y. Enterococcal Bacteriocins and Antimicrobial Proteins that Contribute to Niche Control. In Enterococci: From Commensals to Leading Causes of Drug Resistant Infection; Gilmore, M.S., Clewell, D.B., Ike, Y., Shankar, N., Eds.; Massachusetts Eye and Ear Infirmary: Boston, MA, USA, 2014.

34. Cotter, P.D.; Ross, R.P.; Hill, C. Bacteriocins-A Viable Alternative to Antibiotics? Nat. Rev. Microbiol. 2013, 11, 95-105. [CrossRef]

35. Hanchi, H.; Mottawea, W.; Sebei, K.; Hammami, R. The Genus Enterococcus: Between Probiotic Potential and Safety ConcernsAn Update. Front. Microbiol. 2018, 9, 1-16. [CrossRef] [PubMed]

36. Alvarez-Sieiro, P.; Montalbán-López, M.; Mu, D.; Kuipers, O.P. Bacteriocins of Lactic Acid Bacteria: Extending the Family. Appl. Microbiol. Biotechnol. 2016, 100, 2939-2951. [CrossRef]

37. Zimina, M.; Babich, O.; Prosekov, A.; Sukhikh, S.; Ivanova, S.; Shevchenko, M.; Noskova, S. Overview of Global Trends in Classification, Methods of Preparation and Application of Bacteriocins. Antibiotics 2020, 9, 553. [CrossRef] [PubMed]

38. Maqueda, M.; Sánchez-Hidalgo, M.; Fernández, M.; Montalbán-López, M.; Valdivia, E.; Martínez-Bueno, M. Genetic Features of Circular Bacteriocins Produced by Gram-Positive Bacteria. FEMS Microbiol. Rev. 2008, 32, 2-22. [CrossRef]

39. Chen, H.; Hoover, D.G. Bacteriocins and Their Food Applications. Compr. Rev. Food Sci. Food Saf. 2003, 2, 82-100.

40. Franz, C.M.A.P.; Van Belkum, M.J.; Holzapfel, W.H.; Abriouel, H.; Gálvez, A. Diversity of Enterococcal Bacteriocins and Their Grouping in a New Classification Scheme. FEMS Microbiol. Rev. 2007, 31, 293-310. [CrossRef]

41. Todorov, S.D.; Wachsman, M.B.; Knoetze, H.; Meincken, M.; Dicks, L.M.T. An Antibacterial and Antiviral Peptide Produced by Enterococcus mundtii ST4V Isolated from Soya Beans. Int. J. Antimicrob. Agents 2005, 25, 508-513. [CrossRef]

42. Poeta, P.; Costa, D.; Rojo-Bezares, B.; Zarazaga, M.; Klibi, N.; Rodrigues, J.; Torres, C. Detection of Antimicrobial Activities and Bacteriocin Structural Genes in Faecal Enterococci of Wild Animals. Microbiol. Res. 2007, 162, 257-263. [CrossRef] [PubMed]

43. Comerlato, C.B.; Buboltz, J.R.; Santestevan, N.A. Antimicrobial compounds produced by Enterococcus spp. isolates from fecal samples of wild South American fur seals. J. Microbiol. Antimicrob. 2016, 8, 14-21.

44. Ghomrassi, H.; Hani, K.; Chobert, J.M.; Ghrairi, T. Evaluation of Marine Bacteriocinogenic Enterococci Strains with Inhibitory Activity against Fish-Pathogenic Gram-Negative Bacteria. Dis. Aquat. Organ. 2016, 118, 31-43. [CrossRef] [PubMed]

45. Ogaki, M.B.; Rocha, K.R.; Terra, M.R.; Furlaneto, M.C.; Furlaneto-Maia, L. Screening of the Enterocin-Encoding Genes and Antimicrobial Activity in Enterococcus Species. J. Microbiol. Biotechnol. 2016, 26, 9. [CrossRef]

46. Phumisantiphong, U.; Siripanichgon, K.; Reamtong, O.; Diraphat, P. A Novel Bacteriocin from Enterococcus faecalis 478 Exhibits a Potent Activity against Vancomycin-Resistant Enterococci. PLoS ONE 2017, 12, e0186415. [CrossRef]

47. Rahmeh, R. Characterization of Semipurified Enterocins Produced by Enterococcus faecium Strains Isolated from Raw Camel Milk. J. Dairy Sci. 2016, 101, 4944-4952. [CrossRef]

48. Vandera, E. Approaches for Enhancing in Situ Detection of Enterocin Genes in Thermized Milk, and Selective Isolation of Enterocin-Producing Enterococcus faecium from Baird-Parker Agar. Int. J. Food Microbiol. 2018, 281, 23-31. [CrossRef]

49. Zhao, X.-Q. Genome-Based Studies of Marine Microorganisms to Maximize the Diversity of Natural Products Discovery for Medical Treatments. Evid.-Based Complementary Altern. Med. 2011, 2011, 1-12. [CrossRef]

50. Zhang, M.M. Using Natural Products for Drug Discovery: The Impact of the Genomics Era. Expert. Opin. Drug Discov. 2017, 12, 475-487. [CrossRef]

51. Gregory, K.; Salvador, L.A.; Akbar, S.; Adaikpoh, B.I.; Stevens, D.C. Survey of Biosynthetic Gene Clusters from Sequenced Myxobacteria Reveals Unexplored Biosynthetic Potential. Microorganisms 2019, 7, 181. [CrossRef] [PubMed]

52. Sekurova, O.N.; Schneider, O.; Zotchev, S.B. Novel Bioactive Natural Products from Bacteria via Bioprospecting, Genome Mining and Metabolic Engineering. Microb. Biotechnol. 2019, 12, 828-844. [CrossRef] [PubMed]

53. Xin, B.; Liu, H.; Zheng, J.; Xie, C.; Gao, Y.; Dai, D.; Peng, D.; Ruan, L.; Chen, H.; Sun, M. In Silico Analysis Highlights the Diversity and Novelty of Circular Bacteriocins in Sequenced Microbial Genomes. Msystems 2020, 5, e00047-20. [CrossRef]

54. Bonacina, J.; Suárez, N.; Hormigo, R.; Fadda, S.; Lechner, M.; Saavedra, L. A Genomic View of Food-Related and Probiotic Enterococcus Strains. DNA Res. 2016, 24, 11-24. [CrossRef]

55. Suárez, N.E.; Bonacina, J.; Hebert, E.M.; Saavedra, M.L. Genome Mining and Transcriptional Analysis of Bacteriocin Genes in Enterococcus faecium CRL1879. J. Data Min. Genom. Proteom. 2015, 6, 1-8.

56. Vezina, B.; Rehm, B.H.A.; Smith, A.T. Bioinformatic Prospecting and Phylogenetic Analysis Reveals 94 Undescribed Circular Bacteriocins and Key Motifs. BMC Microbiol. 2020, 20, 1-16. [CrossRef]

57. Blin, K. AntiSMASH 5.0: Updates to the Secondary Metabolite Genome Mining Pipeline. Nucleic Acids Res. 2019, 47, W81-W87. [CrossRef]

58. van Heel, A.J.; de Jong, A.; Song, C.; Viel, J.H.; Kok, J.; Kuipers, O.P. BAGEL4: A User-Friendly Web Server to Thoroughly Mine RiPPs and Bacteriocins. Nucleic Acids Res. 2018, 46, W278-W281. [CrossRef] [PubMed]

59. Richter, M.; Rosselló-Móra, R. Shifting the Genomic Gold Standard for the Prokaryotic Species Definition. Proc. Natl. Acad. Sci. USA 2009, 106, 19126-19131. [CrossRef] 
60. Coburn, P.S. Enterococcus faecalis Senses Target Cells and in Response Expresses Cytolysin. Science 2004, 306, 2270-2272. [CrossRef] [PubMed]

61. Van Tyne, D.; Martin, M.; Gilmore, M. Structure, Function, and Biology of the Enterococcus faecalis Cytolysin. Toxins 2013, 5, 895-911. [CrossRef]

62. Yang, J.; Yan, R.; Roy, A.; Xu, D.; Poisson, J.; Zhang, Y. The I-TASSER Suite: Protein Structure and Function Prediction. Nat. Methods 2015, 12, 7-8. [CrossRef]

63. Zhang, Y. I-TASSER Server for Protein 3D Structure Prediction. BMC Bioinf. 2008, 9, 1-8. [CrossRef]

64. Palmer, K.L.; Godfrey, P.; Griggs, A.; Kos, V.N.; Zucker, J.; Desjardins, C.; Cerqueira, G.; Gevers, D.; Walker, S.; Wortman, J.; et al. Comparative Genomics of Enterococci: Variation in Enterococcus faecalis, Clade Structure in E. faecium, and Defining Characteristics of E. gallinarum and E. casseliflavus. mBio 2012, 3, e00318-11. [CrossRef]

65. Jennes, W.; Dicks, L.M.T.; Verwoerd, D.J. Enterocin 012, a Bacteriocin Produced by Enterococcus gallinarum Isolated from the Intestinal Tract of Ostrich. J. Appl. Microbiol. Biochem. 2000, 88, 349-357. [CrossRef] [PubMed]

66. Ermolenko, E.I. Anti-Influenza Activity of Enterocin B In Vitro and Protective Effect of Bacteriocinogenic Enterococcal Probiotic Strain on Influenza Infection in Mouse Model. Probiotics Antimicrob. Proteins 2019, 11, 705-712. [CrossRef] [PubMed]

67. Al-Fakharany, O.M.; Aziz, A.A.A.; El-Banna, T.E.-S.; Sonbol, F.I. Immunomodulatory and Anticancer Activities of Enterocin Oe-342 Produced by Enterococcus faecalis Isolated from Stool. J. Clin. Cell. Immunol. 2018, 9, 1000558. [CrossRef]

68. Ankaiah, D.; Palanichamy, E.; Antonyraj, C.B.; Ayyanna, R.; Perumal, V.; Ahamed, S.I.B.; Arul, V. Cloning, Overexpression, Purification of Bacteriocin Enterocin-B and Structural Analysis, Interaction Determination of Enterocin-A, B against Pathogenic Bacteria and Human Cancer Cells. Int. J. Biol. Macromol. 2018, 116, 502-512. [CrossRef] [PubMed]

69. Pirkhezranian, Z.; Tanhaeian, A.; Mirzaii, M.; Sekhavati, M.H. Expression of Enterocin-P in HEK Platform: Evaluation of Its Cytotoxic Effects on Cancer Cell Lines and Its Potency to Interact with Cell-Surface Glycosaminoglycan by Molecular Modeling. Int. J. Pept. Res. Ther. 2020, 26, 1503-1512. [CrossRef]

70. Caly, D.L. The Safe Enterocin DD14 Is a Leaderless Two-Peptide Bacteriocin with Anti-Clostridium perfringens Activity. J. Antimicrob. Agents 2017, 49, 282-289. [CrossRef]

71. Mathur, H.; Rea, M.; Cotter, P.; Hill, C.; Ross, R. The Sactibiotic Subclass of Bacteriocins: An Update. CPPS 2015, 16, 549-558. [CrossRef]

72. Bédard, F.; Hammami, R.; Zirah, S.; Rebuffat, S.; Fliss, I.; Biron, E. Synthesis, Antimicrobial Activity and Conformational Analysis of the Class IIa Bacteriocin Pediocin PA-1 and Analogs Thereof. Sci. Rep. 2018, 8, 9029. [CrossRef]

73. Bédard, F.; Biron, E. Recent Progress in the Chemical Synthesis of Class II and S-Glycosylated Bacteriocins. Front. Microbiol. 2018, 9, 1048. [CrossRef] [PubMed]

74. Lander, A.J.; Li, X.; Jin, Y.; Luk, L.Y. Total Chemical Synthesis of Aureocin A53, Lacticin Q and Their Enantiomeric Counterparts. ChemRxiv. Preprint. 2020. [CrossRef]

75. Tanhaeian, A.; Damavandi, M.S.; Mansury, D.; Ghaznini, K. Expression in Eukaryotic Cells and Purification of Synthetic Gene Encoding Enterocin P: A Bacteriocin with Broad Antimicrobial Spectrum. AMB Expr. 2019, 9, 1-9. [CrossRef] [PubMed]

76. Cintas, L.M.; Casaus, P.; Håvarstein, L.S.; Hernández, P.E.; Nes, I.F. Biochemical and Genetic Characterization of Enterocin P, a Novel Sec-Dependent Bacteriocin from Enterococcus faecium P13 with a Broad Antimicrobial Spectrum. Appl. Environ. Microbiol. 1997, 63, 4321-4330. [CrossRef]

77. Nilsen, T.; Nes, I.F.; Holo, H. Enterolysin A, a Cell Wall-Degrading Bacteriocin from Enterococcus faecalis LMG 2333. AEM 2003, 69, 2975-2984. [CrossRef] [PubMed]

78. Khan, H.; Flint, S.H.; Yu, P.-L. Determination of the Mode of Action of Enterolysin A, Produced by Enterococcus faecalis B9510. J. Appl. Microbiol. 2013, 115, 484-494. [CrossRef]

79. Tran, P.N.; Yen, M.-R.; Chiang, C.-Y.; Lin, H.-C.; Chen, P.-Y. Detecting and Prioritizing Biosynthetic Gene Clusters for Bioactive Compounds in Bacteria and Fungi. Appl. Microbiol. Biotechnol. 2019, 103, 3277-3287. [CrossRef]

80. Chu, J.; Vila-Farres, X.; Inoyama, D.; Ternei, M.; Cohen, L.J.; Gordon, E.A.; Reddy, B.V.B.; Charlop-Powers, Z.; Zebroski, H.A.; Gallardo-Macias, R.; et al. Discovery of MRSA Active Antibiotics Using Primary Sequence from the Human Microbiome. Nat. Chem. Biol. 2016, 12, 1004-1006. [CrossRef]

81. Guimarães, A.C.; Meireles, L.M.; Lemos, M.F.; Guimarães, M.C.C.; Endringer, D.C.; Fronza, M.; Scherer, R. Antibacterial Activity of Terpenes and Terpenoids Present in Essential Oils. Molecules 2019, 24, 2471. [CrossRef]

82. Basalla, J.; Chatterjee, P.; Burgess, E.; Khan, M.; Verbrugge, E.; Wiegmann, D.D.; LiPuma, J.J.; Wildschutte, H. Loci Encoding Compounds Potentially Active against Drug-Resistant Pathogens amidst a Decreasing Pool of Novel Antibiotics. Appl. Environ. Microbiol. 2019, 85, e01438-19. [CrossRef] [PubMed]

83. Cappiello, F.; Loffredo, M.R.; Del Plato, C.; Cammarone, S.; Casciaro, B.; Quaglio, D.; Mangoni, M.L.; Botta, B.; Ghirga, F. The Revaluation of Plant-Derived Terpenes to Fight Antibiotic-Resistant Infections. Antibiotics 2020, 9, 325. [CrossRef]

84. Liang, L.; Haltli, B.; Marchbank, D.H.; Fischer, M.; Kirby, C.W.; Correa, H.; Clark, T.N.; Gray, C.A.; Kerr, R.G. Discovery of an Isothiazolinone-Containing Antitubercular Natural Product Levesquamide. J. Org. Chem. 2020, 85, 6450-6462. [CrossRef]

85. Jiang, M.; Wu, Z.; Guo, H.; Liu, L.; Chen, S. A Review of Terpenes from Marine-Derived Fungi: 2015-2019. Mar. Drugs 2020, 18, 321. [CrossRef] [PubMed]

86. Brahmkshatriya, P.P.; Brahmkshatriya, P.S. Terpenes: Chemistry, Biological Role, and Therapeutic Applications. In Natural Products; Ramawat, K.G., Mérillon, J.M., Eds.; Springer: Berlin/Heidelberg, Germany, 2013; pp. 2665-2691. 
87. Chen, R.; Wong, H.; Burns, B. New Approaches to Detect Biosynthetic Gene Clusters in the Environment. Medicines 2019, 6, 32. [CrossRef] [PubMed]

88. Ziko, L.; Adel, M.; Malash, M.N.; Siam, R. Insights into Red Sea Brine Pool Specialized Metabolism Gene Clusters Encoding Potential Metabolites for Biotechnological Applications and Extremophile Survival. Mar. Drugs 2019, 17, 273. [CrossRef]

89. Beukers, A.G. Comparative Genomics of Enterococcus Spp. Isolated from Bovine Feces. BMC Microbiol. 2017, 17, 1-18. [CrossRef]

90. Román, L.; Padilla, D.; Acosta, F.; Sorroza, L.; Fátima, E.; Déniz, S.; Grasso, V.; Bravo, J.; Real, F. The Effect of Probiotic Enterococcus gallinarum L-1 on the Innate Immune Parameters of Outstanding Species to Marine Aquaculture. J. Appl. Anim. Res. 2015, 43, 177-183. [CrossRef]

91. Safari, R.; Adel, M.; Lazado, C.C.; Caipang, C.M.A.; Dadar, M. Host-Derived Probiotics Enterococcus casseliflavus Improves Resistance against Streptococcus iniae Infection in Rainbow Trout (Oncorhynchus mykiss) via Immunomodulation. Fish Shellfish Immunol. 2016, 52, 198-205. [CrossRef]

92. Ringø, E.; Hoseinifar, S.H.; Ghosh, K.; Doan, H.V.; Beck, B.R.; Song, S.K. Lactic Acid Bacteria in Finfish-An Update. Front. Microbiol. 2018, 9, 1818. [CrossRef]

93. Rubner-Institute, M. Enterococci as Probiotics and Their Implications in Food Safety. Int. J. Food Microbiol. 2001, 151, 125-140.

94. Huys, G.; Botteldoorn, N.; Delvigne, F.; De Vuyst, L.; Heyndrickx, M.; Pot, B.; Dubois, J.; Daube, G. Microbial Characterization of Probiotics-Advisory Report of the Working Group "8651 Probiotics" of the Belgian Superior Health Council (SHC). Mol. Nutr. Food Res. 2013, 57, 1479-1504. [CrossRef] [PubMed]

95. Joseph, J.P. Probiotic genomes: Sequencing and annotation in the past decade. Int. J. Pharm. Sci. Res. 2018, 9, 1351-1362.

96. Donia, M.S.; Fischbach, M.A. Small Molecules from the Human Microbiota. Science 2016, 349, 1254766. [CrossRef] [PubMed]

97. Hashempour-Baltork, F.; Hosseini, H.; Shojaee-Aliabadi, S.; Torbati, M.; Alizadeh, A.M.; Alizadeh, M. Drug Resistance and the Prevention Strategies in Food Borne Bacteria: An Update Review. Adv. Pharm. Bull. 2019, 9, 335-347. [CrossRef]

98. Prichula, J.; Pereira, R.I.; Wachholz, G.R.; Cardoso, L.A.; Tolfo, N.C.C.; Santestevan, N.A.; Medeiros, A.W.; Tavares, M.; Frazzon, J.; d'Azevedo, P.A.; et al. Resistance to Antimicrobial Agents among Enterococci Isolated from Fecal Samples of Wild Marine Species in the Southern Coast of Brazil. Mar. Pollut. Bull. 2016, 105, 51-57. [CrossRef]

99. Santestevan, N.A. Antimicrobial Resistance and Virulence Factor Gene Profiles of Enterococcus Spp. Isolates from Wild Arctocephalus australis (South American Fur Seal) and Arctocephalus tropicalis (Subantarctic Fur Seal). World J. Microbiol. Biotechnol. 2015, 31, 1935-1946. [CrossRef]

100. Haft, D.H.; DiCuccio, M.; Badretdin, A.; Brover, V.; Chetvernin, V.; O’Neill, K.; Li, W.; Chitsaz, F.; Derbyshire, M.K.; Gonzales, N.R.; et al. RefSeq: An Update on Prokaryotic Genome Annotation and Curation. Nucleic Acids Res. 2018, 46, D851-D860. [CrossRef]

101. Richter, M.; Rossello, R.J. Species WS: A Web Server for Prokaryotic Species Circumscription Based on Pairwise Genome Comparison. Bioinformatics 2016, 32, 929-931. [CrossRef] [PubMed]

102. Katoh, K.; Kuma, K.; Toh, H.; Miyata, T. MAFFT Version 5: Improvement in Accuracy of Multiple Sequence Alignment. Nucleic Acids Res. 2005, 33, 511-518. [CrossRef] [PubMed]

103. Sela, I.; Ashkenazy, H.; Katoh, K.; Pupko, T. GUIDANCE 2: Accurate Detection of Unreliable Alignment Regions Accounting for the Uncertainty of Multiple Parameters. Nucleic Acids Res. 2015, 43, W7-W14. [CrossRef] [PubMed]

104. Müller, T.; Vingron, M. Modeling Amino Acid Replacement. J. Comput. Biol. 2000, 7, 761-776. [CrossRef]

105. Lefort, V.; Longueville, J.-E.; Gascuel, O. SMS: Smart Model Selection in PhyML. Mol. Biol. Evol. 2017, 34, 2422-2424. [CrossRef]

106. Anisimova, M.; Gascuel, O. Approximate Likelihood-Ratio Test for Branches: A Fast, Accurate, and Powerful Alternative. Syst. Biol. 2006, 55, 539-552. [CrossRef] [PubMed]

107. Hordijk, W.; Gascuel, O. New Algorithms and Methods to Estimate Maximum-Likelihood Phylogenies: Assessing the Performance of PhyML 3.0. Syst. Biol. 2010, 59, 307-321.

108. Letunic, I.; Bork, P. Interactive Tree Of Life (ITOL) v4: Recent Updates and New Developments. Nucleic Acids Res. 2019, 47, W256-W259. [CrossRef]

109. Pettersen, E.F.; Goddard, T.D.; Huang, C.C.; Couch, G.S.; Greenblatt, D.M.; Meng, E.C.; Ferrin, T.E. UCSF Chimera-A Visualization System for Exploratory Research and Analysis. J. Comput. Chem. 2004, 25, 1605-1612. [CrossRef]

110. Gasteiger, E.; Hoogland, C.; Gattiker, A.; Wilkins, M.R.; Appel, R.D.; Bairoch, A. Protein identification and analysis tools on the ExPASy server. In The Proteomics Protocols Handbook; Walker, J.M., Ed.; Humana Press: Totowa, NJ, USA, 2005 ; pp. 571-607.

111. Jia, B.; Raphenya, A.R.; Alcock, B.; Waglechner, N.; Guo, P.; Tsang, K.K.; Lago, B.A.; Dave, B.M.; Pereira, S.; Sharma, A.N.; et al. CARD 2017: Expansion and Model-Centric Curation of the Comprehensive Antibiotic Resistance Database. Nucleic Acids Res. 2017, 45, D566-D573. [CrossRef]

112. Zankari, E.; Hasman, H.; Cosentino, S.; Vestergaard, M.; Rasmussen, S.; Lund, O.; Aarestrup, F.M.; Larsen, M.V. Identification of Acquired Antimicrobial Resistance Genes. J. Antimicrob. Chemoth. 2012, 67, 2640-2644. [CrossRef]

113. Joensen, K.G.; Scheutz, F.; Lund, O.; Hasman, H.; Kaas, R.S.; Nielsen, E.M.; Aarestrup, F.M. Real-Time Whole-Genome Sequencing for Routine Typing, Surveillance, and Outbreak Detection of Verotoxigenic Escherichia Coli. J. Clin. Microb. 2014, 52, 1501-1510. [CrossRef] 
114. Bostock, M.; Ogievetsky, V.; Heer, J. D3 Data-Driven Documents. IEEE Trans. Visual. Comput. Graph. 2011, 17, $2301-2309$. [CrossRef] [PubMed]

115. R Core Team. R: A Language and Environment for Statistical Computing; R Foundation for Statistical Computing: Vienna, Austria. Available online: https:/ /www.R-project.org/ (accessed on 18 December 2019). 